\title{
Germination of Goldenweed Seed
}

\author{
H.S. MAYEUX, JR., and C.J. SCIFRES
}

Highlight: Large, well-filled seed of Drummond's goldenweed (Isocoma Drummondii (T.\&G.) Greene) germinated in excess of $80 \%$ over a broad range of continuous temperatures $\left(10\right.$ to $\left.25^{\circ} \mathrm{C}\right)$. Germination of Drummond's and common goldenweed (Isocoma coronopifolia (Gray) Greene) seed was about $\mathbf{2 0} \%$ higher under alternating than constant temperature regimes, and 20 to $\mathbf{3 0} \%$ lower in absence of light. Germination and early seedling growth were reduced by -4 and -2 bars simulated moisture stress, respectively. Germination and early seedling vigor were relatively tolerant of extremes of $\mathrm{pH}$, but $\mathrm{NaCl}$ concentrations of $5,000 \mathrm{ppm}$ or higher reduced germination. Drummond's goldenweed seed viability decreased significantly after 200 days storage at room conditions, and no achenes of either species germinated after storage for 15 months. Seed collected from robust plants growing on deep, fertile soil had a higher percent germination than those of plants growing under less favorable conditions, although unimbibed achene weight did not differ. No seed dormancy mechanisms were observed. Initial seedling establishment apparently depends primarily on the occurrence of adequate rainfall in late winter and early spring.

Members of the genus Isocoma (Compositae) are perennial subshrubs, heavily branched from a woody base (Fig. 1). Their rounded canopies rarely exceed $1 \mathrm{~m}$ in height, and they produce yellow, rayless flowers in fall and winter. The foliage is resinous, aromatic, and apparently not palatable to livestock or wildlife.

Three species of the genus occur in Texas. Rayless goldenrod (Isocoma Wrightii (Gray) Rydb.) is a poisonous range plant restricted primarily to the Trans-Pecos and occasionally found on the High Plains of Texas. Common goldenweed (Isocoma coronopifolia (Gray) Greene) apparently occurs only on the South Texas Plains (Gould 1969), while Drummond's goldenweed (Isocoma Drummondii (T.\&G.) Greene) inhabits the southern Coastal Prairie.

The goldenweeds produce large numbers of pubescent achenes, 2 to $3 \mathrm{~mm}$ in length. The achene is attached to a persistent pappus consisting of many unequal bristles, two or three times as long as the achene, which affords the mechanism for spread.

Common and Drummond's goldenweeds are currently demanding the attention of natural resource managers as locally important weeds. Although both species are increasing in abundance and density on rangeland and improved pastures, Correll and Johnston (1970) describe Drummond's goldenweed as the "more aggressive, weedy species." The lack of basic information on their reproductive potential prompted laboratory investigations of simulated envi-

Authors are research agronomist, U.S. Department of Agriculture, Science Education Administration - Federal Research, Grassland-Forage Research Center. P.O. Box 748. Temple. Texas 76501; and professor, Department of Range Science. Texas A\&M University, College Station 77843. Senior author was formerly graduate research assistant, Texas Agricultural Experiment Station. College Station.

Research was approved by the Director, Texas Agricultural Experiment Station, as TA 13514

Manuscript received October 3, 1977. ronmental influences on germination of Drummond's and common goldenweed seed.

\section{Materials and Methods}

Seed were randomly collected from a Drummond's goldenweed population in Kleberg county during December, 1973, 1974, and 1975. Common goldenweed seed were collected in Zavala county during November of the same years. All seed were stored in polyethylene-lined cloth bags at room conditions. Large seed which were apparently fully developed and undamaged were hand selected and used for germination experiments.

All germination experiments were conducted in small growth chambers with automatic temperature and light controls. An experimental unit consisted of 20 achenes in a $9-\mathrm{cm}$ petri dish containing two filter papers wetted with $9 \mathrm{ml}$ of distilled water or appropriate test solution. If temperature was not an intended variable, experiments were conducted at constant $20^{\circ} \mathrm{C}$, with fluorescent light providing an 8-hr photoperiod. Treatments were replicated 5 to 20 times, and each experiment was conducted at
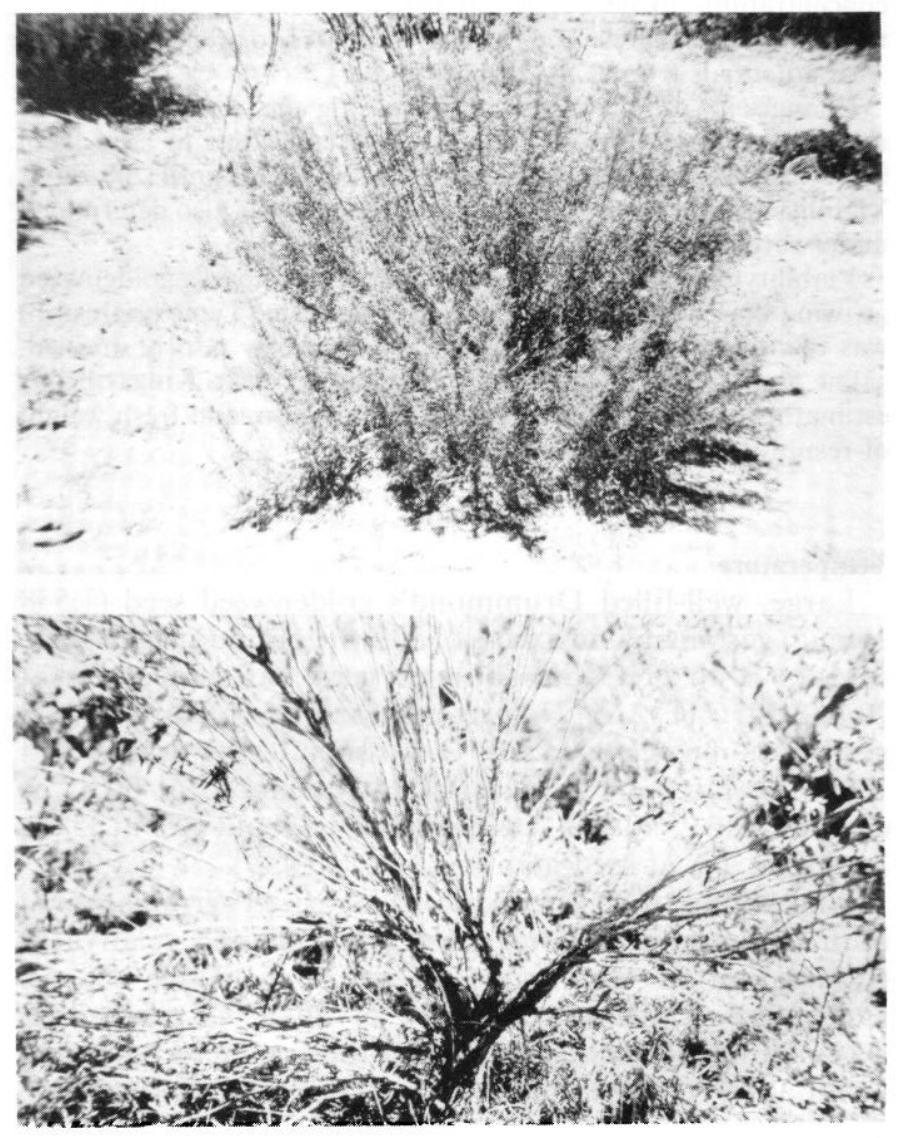

Fig. 1. A mature common goldenweed plant in late summer near Zapata in the South Texas Plains (upper), and the basal portion of a Drummond's goldenweed near Riviera in the Coastal Prairie, showing woody main stem and extensive branching (lower). 
least twice. All experiments were designed as randomized complete blocks. When both species were included in a single experiment, a split-plot arrangement was employed, assigning species as mainplot effects and treatments as sub-plots. An achene was considered germinated if the radicle protruded $2 \mathrm{~mm}$, and cumulative percent germination was recorded after 10 or 20 days. Germination data were subjected to the arcsin $\sqrt{\%}$ transformation prior to conducting analysis of variance. Fresh weights and radicle lengths of ten seedlings from each replication were recorded at 20 days after initiation of selected experiments. Differences among means were compared with Duncan's multiple range test unless otherwise noted.

Drummond's goldenweed seed were germinated under continuous temperatures in $5^{\circ} \mathrm{C}$ increments from 0 to $40^{\circ} \mathrm{C}$. Both Drummond's and common goldenweed seed were studied in a separate comparison with continuous temperatures of 10,20 , and $30^{\circ} \mathrm{C}$, and alternating regimes of $10-20$ and $20-30^{\circ} \mathrm{C}(16 \mathrm{hr}$ low temperature, $8 \mathrm{hr}$ high temperature with light).

Light requirement was investigated by comparing germination in petri dishes covered with aluminum foil with germination in uncovered dishes. As in all subsequent experiments, light requirement was evaluated under the optimum temperature regime.

Hydrogen ion concentration of distilled water was adjusted by adding $\mathrm{HCl}$ or $\mathrm{KOH}$. A range of $\mathrm{pH}$ values from 2 to 12 in unit increments was used. Salt effects on germination were evaluated with aqueous solutions of varying $\mathrm{NaCl}$ concentrations. Concentrations of $\mathrm{NaCl}$ were $0,0.5,1,5,10,15$ and $20 \times 10^{3} \mathrm{ppm}$ (wt/vol).

Increasing concentrations of polyethylene glycol (PEG) 6000 were used to adjust osmotic potentials of distilled water to determine effects of moisture stress on seed germination and early seedling development of the goldenweeds. Michel and Kaufmann (1973) employed thermocouple psychrometers, vapor pressure osmometers, and viscometers to develop tables of PEG 6000 concentrations to give required osmotic potentials over a wide range of temperatures. Their results were used to prepare solutions with potentials from 0 to -12 bars at $20^{\circ} \mathrm{C}$.

Changes in seed viability with increasing age were evaluated by initiating germination on the day after collection of seed from intact floral structures and at 40-day intervals until 200 days. Viability of seed stored for 15 and 18 months was also determined under several temperature regimes.

Viability of seed produced by robust Drummond's goldenweed growing on a deep, fertile grey sandy loam site (Typic haplustoll) was compared with that of plants on a nearby poorly drained, saline tight sandy loam (Aguic palcustalf) near Kingsvillc by estimating unimbibed seed weight, germination, and fresh weight of resulting seedlings.

\section{Results}

\section{Temperature}

Large, well-filled Drummond's goldenweed seed (1,538 seed $/ \mathrm{g}$ ) germinated in excess of $80 \%$ at continuous temperatures of 10 to $25^{\circ} \mathrm{C}$, but optimum germination occurred at 20 and $25^{\circ} \mathrm{C}$ (Fig. 2). No germination occurred at $0^{\circ} \mathrm{C}$ and germination percentage at $5^{\circ} \mathrm{C}$ was significantly less than at $10^{\circ} \mathrm{C}$. Germination was significantly reduced at $30^{\circ} \mathrm{C}$ as compared to $25^{\circ} \mathrm{C}$ and was decreased to about $10 \%$ at $35^{\circ} \mathrm{C}$. Less than $1 \%$ of seed germinated at $40^{\circ} \mathrm{C}$.

Alternating $10-20^{\circ} \mathrm{C}$ conditions increased germination of both common and Drummond's goldenweed relative to germination at continuous 10 or $20^{\circ} \mathrm{C}$ (Table 1). An alternating temperature regime of $20-30^{\circ} \mathrm{C}$ resulted in germination percentages equal to those of seed subjected continuously to the lower temperature and greater than those of seeds subjected continuously to the higher temperature. Variation between the two temperature experiments relative to absolute germination percentages of Drummond's goldenweed was attributed to general viability of the

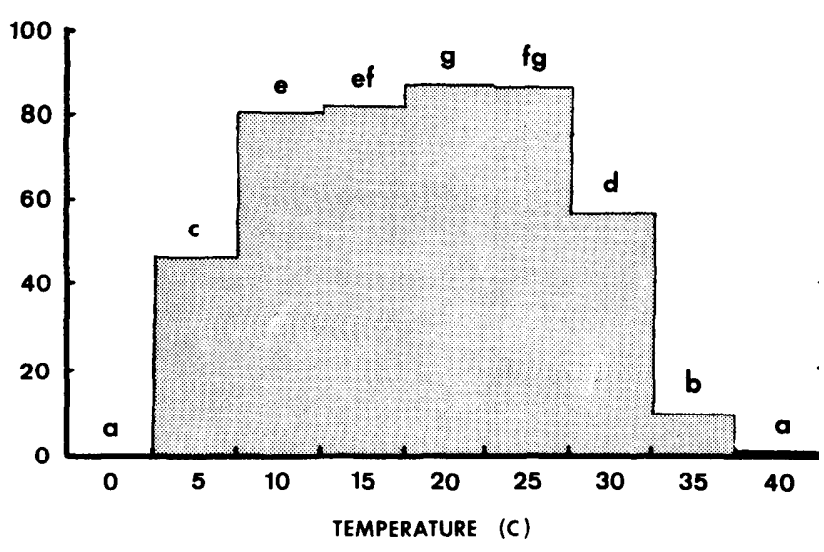

Fig. 2. Average percentage of Drummond's goldenweed seed that germinated after 20 days at nine constant temperatures. Plateaus designated with the same letter do not differ significantly at the $95 \%$ confidence level.

two collections used. The seed lots were collected from the same site. However, one collection was made in 1974 and the other in 1975, indicating that yearly variation in growth conditions may affect seed viability.

\section{Light}

Germination levels of common and Drummond's goldenweed were reduced by about 30 and $20 \%$, respectively, in darkness as compared to germination with daily 8-hr periods of light (data not shown). Cotyledons of embryos germinated in darkness were not unfolded, whereas the cotyledons of those germinated in light were fully expanded at the time of evaluation.

\section{Hydrogen Ion and $\mathrm{NaCl}$ Effects}

Percentage of Drummond's goldenweed seed germinated after 10 days was greatly reduced at $\mathrm{pH} 2$ but only slightly depressed at pH 12 as compared with germination percentages at other hydrogen ion concentrations (Table 2). No trend was apparent for germination of seed subjected to less extreme acid or alkaline conditions since responses were not significantly different in the $\mathrm{pH}$ range of 3 to 11 . Radicle lengths of germinated seed were somewhat more sensitive to hydrogen ion concentration, although no differences were observed among them at $\mathrm{pH}$ levels between 4 and 10. Fresh weights of seedlings tended to be greater in acidic than in neutral or basic media.

Salt effects of solutions used in the $\mathrm{pH}$ experiments had no apparent influence on achene germination (Table 2).

Table 1. Average germination percentage of common and Drummond's goldenweed seed after $\mathbf{2 0}$ days under various alternating and constant temperature regimes ${ }^{\mathrm{a}}$.

\begin{tabular}{ccc}
\hline $\begin{array}{c}\text { Temperature } \\
\text { regime } \\
\left({ }^{\circ} \mathrm{C}\right)\end{array}$ & $\begin{array}{c}\text { Sommon } \\
\text { goldenweed } \\
(\%)\end{array}$ & $\begin{array}{c}\text { Drummond's } \\
\text { goldenweed } \\
(\%)\end{array}$ \\
\hline Constant 10 & $50 \mathrm{~b}$ & $37 \mathrm{c}$ \\
Alternate 10-20 & $60 \mathrm{a}$ & $48 \mathrm{~b}$ \\
Constant 20 & $52 \mathrm{~b}$ & $40 \mathrm{c}$ \\
Alternate 20-30 & $51 \mathrm{~b}$ & $37 \mathrm{c}$ \\
Constant 30 & $20 \mathrm{e}$ & $38 \mathrm{~d}$ \\
\hline
\end{tabular}

a Means followed by the same letter do not differ significantly at the $95 \%$ confidence level. 
Table 2. Average germination percentage of Drummond's goldenweed seed, average radicle lengths, and average fresh weights of seedlings after 10-days exposure to solutions of various $\mathrm{pH}^{\mathrm{a}}$.

\begin{tabular}{cccc}
\hline pH & $\begin{array}{c}\text { Germination } \\
(\%)\end{array}$ & $\begin{array}{c}\text { Radicle } \\
\text { length } \\
(\mathrm{mm})\end{array}$ & $\begin{array}{c}\text { Seedling } \\
\text { weight } \\
(\mathrm{mg})\end{array}$ \\
\hline 2 & $16 \mathrm{c}$ & $1.2 \mathrm{~d}$ & $1.5 \mathrm{f}$ \\
3 & $86 \mathrm{a}$ & $6.6 \mathrm{c}$ & $7.7 \mathrm{c}$ \\
4 & $86 \mathrm{a}$ & $7.8 \mathrm{~b}$ & $8.8 \mathrm{ab}$ \\
5 & $83 \mathrm{a}$ & $8.9 \mathrm{~b}$ & $8.4 \mathrm{bc}$ \\
6 & $83 \mathrm{a}$ & $9.0 \mathrm{~b}$ & $8.9 \mathrm{ab}$ \\
7 & $84 \mathrm{a}$ & $8.7 \mathrm{~b}$ & $8.3 \mathrm{bc}$ \\
8 & $88 \mathrm{a}$ & $8.8 \mathrm{~b}$ & $7.6 \mathrm{c}$ \\
9 & $84 \mathrm{a}$ & $8.8 \mathrm{~b}$ & $7.5 \mathrm{c}$ \\
10 & $84 \mathrm{a}$ & $8.2 \mathrm{~b}$ & $7.5 \mathrm{c}$ \\
11 & $80 \mathrm{ab}$ & $6.0 \mathrm{c}$ & $5.7 \mathrm{~d}$ \\
12 & $73 \mathrm{~b}$ & $2.1 \mathrm{~d}$ & $4.1 \mathrm{e}$ \\
Unadjusted & & $11.0 \mathrm{a}$ & $9.5 \mathrm{a}$ \\
control & $85 \mathrm{a}$ &
\end{tabular}

${ }^{a}$ Means within a column followed by the same letter do not differ significantly at the 95\% confidence level.

${ }^{b}$ Distilled water only ( $\mathrm{pH}$ 6.7); no $\mathrm{HCl}$ or $\mathrm{KOH}$ added.

However, seedling growth was adversely affected. Radicle lengths and fresh weights of seedlings germinated in distilled water $(\mathrm{pH}$ 6.7) were greater than those germinated in solutions with $\mathrm{pH}$ adjusted to 7.

Increasing $\mathrm{NaCl}$ concentration of the germination medium to $1,000 \mathrm{ppm}$ tended to reduce Drummond's goldenweed germination, and germination was significantly suppressed at 5,000 ppm (Fig. 3). NaCl concentrations of 10,000 and $15,000 \mathrm{ppm}$ reduced germination to less than $20 \%$. No seed germinated at $20,000 \mathrm{ppm} \mathrm{NaCl}$.

\section{Moisture Availability}

Germination of seed of both goldenweed species was highly sensitive to moisture stress. Percent germination was significantly reduced at -4 bars and was essentially prevented at -10 bars (Table 3 ). Germination of other composites such as Scotch thistle (Onopordium acanthium L.) is not significantly reduced at -8 bars tension (Scifres and McCarty 1969). With the exception of the apparent promotion of common goldenweed radicle lengths at -2 bars, decreasing moisture availability progressively reduced seedling vigor based on data for radicle lengths and fresh weight.

\section{Age Effects}

Viability of Drummond's goldenweed seed decreased significantly $(p=0.05)$ from about 80 to $60 \%$ after less than 7 months storage under room conditions (darkness and

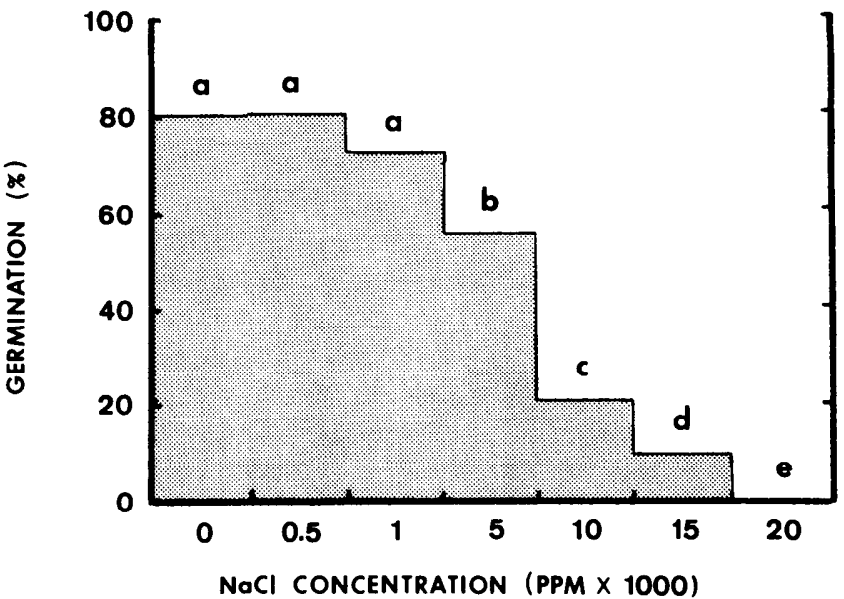

Fig. 3. Average percentage of Drummond's goldenweed seed that germinated after 10-day's exposure to various concentrations of sodium chloride. Plateaus designated with the same letter do not differ significantly at the $95 \%$ level.

temperatures of 22 to $25^{\circ} \mathrm{C}$ ) (data not shown). No achenes of either species germinated after storage for 15 months, regardless of temperature conditions. Sperry (1953) indicated that seed of the closely related rayless goldenrod probably do not retain viability beyond the first year.

\section{Site Effects}

Viability of Drummond's goldenweed seed produced by large, robust plants was greater than that of seed from less vigorous plants grown on a site characterized by adverse soil conditions (low fertility, poor drainage, saline and sodic conditions) (Table 4). Although unimbibed seed weights did

Table 4. Average germination percentage, weights of unimbibed seed, and fresh weights of seedlings from Drummond's goldenweed seed collected on two sites near Riviera, Texas.

\begin{tabular}{|c|c|c|c|}
\hline \multirow{2}{*}{ Site } & \multirow{2}{*}{$\begin{array}{c}\text { Germination } \\
(\%)\end{array}$} & \multicolumn{2}{|c|}{ Weight } \\
\hline & & $\begin{array}{l}\text { Achenes } \\
\text { (mg) }\end{array}$ & $\begin{array}{l}\text { Seedlings } \\
(\mathrm{mg})\end{array}$ \\
\hline $\begin{array}{c}\text { Grey } \\
\text { sandy loam }\end{array}$ & 74 & 0.642 & 9.38 \\
\hline $\begin{array}{c}\text { Tight } \\
\text { sandy loam }\end{array}$ & 65 & 0.650 & 8.67 \\
\hline Difference & 9 & 0.008 & 0.71 \\
\hline LSD $(90 \%)$ & 5 & 0.012 & 0.66 \\
\hline LSD $(95 \%)$ & 6 & 0.017 & 0.78 \\
\hline
\end{tabular}

Table 3. Average germination percentage of common (CG) and Drummond's goldenweed (DG) seed, average radicle lengths, and average fresh weights of seedlings after 10-days exposure to germination media of various osmotic potentials ${ }^{2}$.

\begin{tabular}{|c|c|c|c|c|c|c|}
\hline \multirow{2}{*}{$\begin{array}{c}\text { Osmotic } \\
\text { potential } \\
\text { (-bars) }\end{array}$} & \multicolumn{2}{|c|}{$\begin{array}{c}\text { Germination } \\
(\%)\end{array}$} & \multicolumn{2}{|c|}{$\begin{array}{l}\text { Radicle length } \\
(\mathrm{mm})\end{array}$} & \multicolumn{2}{|c|}{$\begin{array}{l}\text { Seedling weight } \\
\text { (mg) }\end{array}$} \\
\hline & $C G$ & $\mathrm{DG}$ & $\mathrm{CG}$ & $\mathrm{DG}$ & $\mathrm{CG}$ & $\mathrm{DG}$ \\
\hline 0 & $58 \mathrm{a}$ & $84 \mathrm{a}$ & $12.3 \mathrm{~b}$ & $12.4 \mathrm{a}$ & $5.9 \mathrm{a}$ & $8.3 \mathrm{a}$ \\
\hline 2 & $54 \mathrm{ab}$ & $82 \mathrm{ab}$ & $15.6 \mathrm{a}$ & $11.1 \mathrm{~b}$ & $4.6 \mathrm{~h}$ & $3.7 \mathrm{~b}$ \\
\hline 4 & $51 \mathrm{~b}$ & $77 \mathrm{~b}$ & $9.2 \mathrm{c}$ & $5.9 c$ & $2.4 \mathrm{c}$ & $2.6 \mathrm{c}$ \\
\hline 6 & $49 \mathrm{~b}$ & $59 \mathrm{c}$ & $5.2 \mathrm{~d}$ & $4.2 \mathrm{~d}$ & $1.5 \mathrm{~d}$ & $1.8 \mathrm{~d}$ \\
\hline 8 & $9 \mathrm{c}$ & $35 \mathrm{~d}$ & $2.1 \mathrm{e}$ & $3.3 \mathrm{~d}$ & $0.8 \mathrm{e}$ & $1.3 \mathrm{~d}$ \\
\hline 10 & $0 \mathrm{~d}$ & $2 \mathrm{e}$ & $0 \mathrm{f}$ & $0.4 \mathrm{e}$ & $0 \mathrm{f}$ & $0.8 \mathrm{de}$ \\
\hline 12 & $0 \mathrm{~d}$ & $0 \mathrm{f}$ & $0 \mathrm{f}$ & $0 \mathrm{e}$ & () $\mathrm{f}$ & $0 \mathrm{e}$ \\
\hline
\end{tabular}

aMeans within a column followed by the same letter do not differ significantly at the $95 \%$ confidence level. 
not differ, average fresh weight of germinated seedlings from the deep, fertile site were significantly greater at the $90 \%$ level of probability.

\section{Conclusions}

Germination of Drummond's goldenweed seed is not restricted to a narrow temperature range, but is favored by mild temperatures and diurnal fluctation. At Kingsville, the site of seed collection, mean monthly temperatures for December through April (Carr 1967) fall within the range of continuous temperatures which allow germination in excess of $80 \%$. Under natural conditions near Kingsville, goldenweed seed germinate with the first rains which follow seed dissemination in December and January (Mayeux and Scifres 1977). However, rainfall peaks on the southern Coastal Prairie of Texas occur later, in May and June, and during the fall. Average monthly precipitation is relatively low during the 5 months following the usual time of seed dissemination (Carr 1967). In view of the comparatively brief period of high seed viability, successful germination and initial establishment of substantial numbers of seedlings may be restricted to rare years of high early spring rainfall. The exceptionally high moisture requirement for Drummond's and common goldenweed germination and early growth ccrtainly enhances and enforces this dependence.

Drummond's goldenweed germination does not tolerate moderate to high salt concentrations. This could be a response to osmotic stress, in conjunction with direct salt effects. No achenes of either goldenweed species germinated in experiments in which McIlvain's buffer (Hodgeman et al. 1958) was used to adjust $\mathrm{pH}$, presumably due to salt effects.
McIlvain's buffer has been used successfully in germination experiments with other species (Scifres and McCarty 1969; Scifres 1974) which apparently are less susceptible to salt concentration than goldenweeds. Salt effects also probably contributed to the decreases in radicle length and seedling fresh weight noted in $\mathrm{pH}$ experiments with $\mathrm{HCl}$ and $\mathrm{KOH}$, as compared to these characteristics in seedlings developed in distilled water. Otherwise, Drummond's goldenweed seems unusually tolerant of variation in hydrogen ion concentration. No dormancy mechanisms were apparent relative to germination of either common or Drummond's goldenweed seed.

\section{Literature Cited}

Carr, J. T. 1967. The climate and physiography of Texas. Texas Water Devel. Board Rep. 53, Austin. 27 p.

Correll, Donovan, and M. C. Johnston. 1970. Manual of the vascular plants of Texas. Tex. Res. Found., Renner. 1881 p.

Gould, F. W. 1969. Texas plants: A checklist and ecological summary. Tex. Agr. Exp. Sta. MP-585. 121 p.

Hodgeman, C. D., R. C. Weast, and E. M. Selby. 1958. Handbook of chemistry and physics. Chemical Rubber Co., Cleveland, Ohio. p. 1715.

Mayeux, H. S., Jr., and C. J. Scifres. 1977. Establishment, growth, and development of Drummond's goldenweed. Proc. S. Weed Sci. Soc. 30:231 (abstr.).

Michel, B. E., and M. R. Kaufmann. 1973. The osmotic potential of polyethylene glycol 6000. Plant Physiol. 51:914-916.

Scifres, C. J. 1974. Salient aspects of huisache seed germination. Southwest. Natur. 18:383-391.

Scifres, C. J., and M. K. McCarty. 1969. Some factors affecting germination and seedling growth of Scotch thistle. Nebraska Agr. Exp. Sta. Res. Bull. 228. 28 p.

Sperry, O. E. 1953. Rayless goldenrod -- a poisonous range plant in Texas. J. Range Manage. 6:6-10.

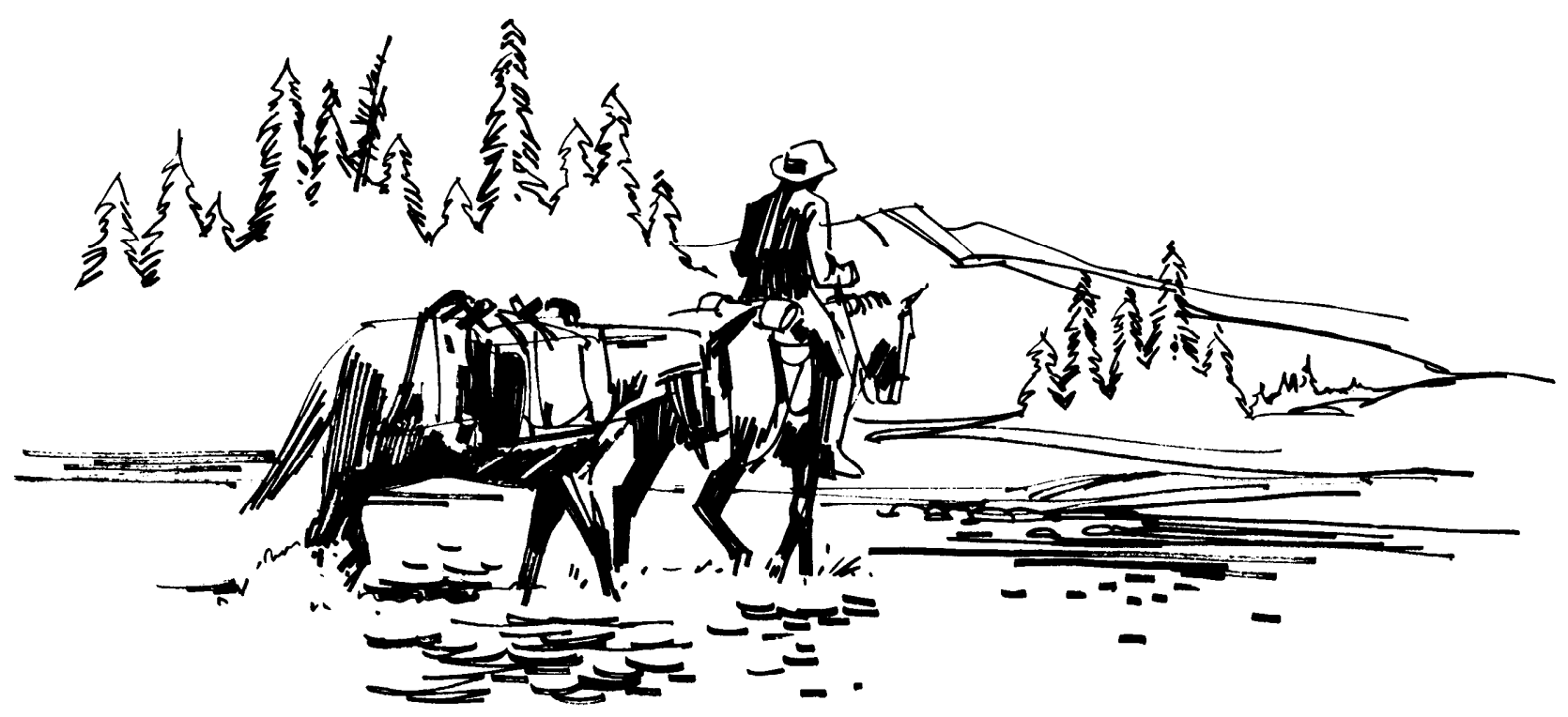

